FINANCIAL ASPECTS OF MARKETING 


\title{
Financial Aspects of Marketing
}

\author{
Ruth A. Schmidt \\ and \\ Helen Wright
}

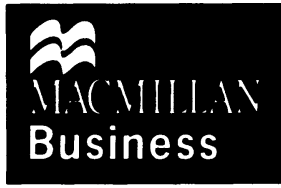


(C) Ruth A. Schmidt and Helen Wright 1996

All rights reserved. No reproduction, copy or transmission of this publication may be made without written permission.

No paragraph of this publication may be reproduced, copied or transmitted save with written permission or in accordance with the provisions of the Copyright, Designs and Patents Act 1988, or under the terms of any licence permitting limited copying issued by the Copyright Licensing Agency, 90 Tottenham Court Road, London W1P 9HE.

Any person who does any unauthorised act in relation to this publication may be liable to criminal prosecution and civil claims for damages.

First published 1996 by MACMILLAN PRESS LTD

Houndmills, Basingstoke, Hampshire RG21 6XS

and London

Companies and representatives

throughout the world

ISBN 978-0-333-63782-1

ISBN 978-1-349-25020-2 (eBook)

DOI 10.1007/978-1-349-25020-2

A catalogue record for this book is available from the British Library.

$\begin{array}{rrrrrrrrrr}10 & 9 & 8 & 7 & 6 & 5 & 4 & 3 & 2 & 1 \\ 05 & 04 & 03 & 02 & 01 & 00 & 99 & 98 & 97 & 96\end{array}$

Typeset in Great Britain by Aarontype Limited

Easton, Bristol 


\section{Contents}

List of Figures

1 Introduction to the Finance and Marketing Interface

1.1 Background and target readership

1.2 Additional equipment required

1.3 Structure

1.4 Progression through the text

PART I INTRODUCTION TO FINANCIAL STATEMENTS

2 The Balance Sheet

2.1 Learning objectives

2.2 Introduction

2.3 Defining the balance sheet

2.4 Assets

2.5 Liabilities

2.6 Capital

2.7 Impact of business transactions on the balance sheet

2.8 Summary

3 The Cash Flow Statement and the Profit and Loss Account 15

$\begin{array}{ll}3.1 & \text { Learning objectives } \\ 3.2 & 15\end{array}$

$\begin{array}{ll}3.2 & \text { The cash flow statement } \\ 3.3 & 15\end{array}$

\begin{tabular}{ll}
3.3 & Business objectives \\
\hline
\end{tabular}

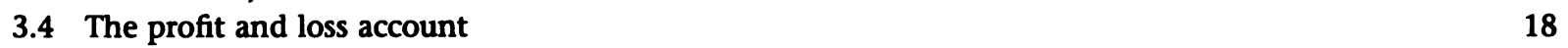

$\begin{array}{lr}3.5 \text { Summary } & 20\end{array}$ 
4 The Matching Concept: Stock Valuation and Depreciation 21

\begin{tabular}{ll}
4.1 & Learning objectives \\
\hline
\end{tabular}

\begin{tabular}{lr}
4.2 & The matching concept \\
\hline
\end{tabular}

$\begin{array}{llr}4.3 & \text { Stock valuation } & 21\end{array}$

\begin{tabular}{lr}
4.4 & Profit calculation: the impact of stock valuation \\
\hline
\end{tabular}

\begin{tabular}{ll}
4.5 & Depreciation \\
\hline
\end{tabular}

4.6 Impact of depreciation method on net profit $\quad 28$

$\begin{array}{llr}4.7 & \text { Summary } & 29\end{array}$

5 Reconciliation of Financial Statements $\quad 31$

$\begin{array}{llr}5.1 & \text { Learning objectives } & 31\end{array}$

\begin{tabular}{ll}
5.2 & Recording the movements of working capital \\
\hline
\end{tabular}

$\begin{array}{llr}5.3 & \text { Summary } & 36\end{array}$

6 Introduction to Spreadsheets: Calculations and Charts $\quad 37$

\begin{tabular}{lr}
6.1 & Learning objectives \\
\hline
\end{tabular}

$\begin{array}{lr}\text { 6.2 What is a spreadsheet? } & 37\end{array}$

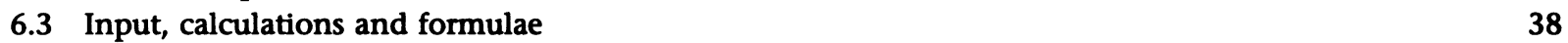

6.4 Enhancing the appearance of a worksheet $r$

\begin{tabular}{lr}
6.5 & Printing and saving a worksheet \\
\hline
\end{tabular}

\begin{tabular}{ll}
6.6 & Absolute cell references \\
\hline
\end{tabular}

6.7 Spreadsheet templates $r$

$\begin{array}{llr}6.8 & \text { Drawing charts } & 44\end{array}$

\begin{tabular}{lr}
6.9 & Printing out charts \\
\hline
\end{tabular}

$\begin{array}{lr}6.10 \text { Summary } & 49\end{array}$

$\begin{array}{ll}\text { Case Study } 1 \text { McTucky's Ltd: Final Accounts } & 50\end{array}$

$\begin{array}{ll}\text { PART II RATIO ANALYSIS } & 53\end{array}$

7 Introduction to Ratio Analysis $\quad 55$

$\begin{array}{llr}7.1 & \text { Learning objectives } & 55\end{array}$

\begin{tabular}{ll}
7.2 & Interpretation of financial statements \\
\hline
\end{tabular}

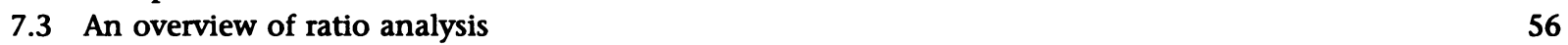

$\begin{array}{ll}7.4 \text { Summary } & 57\end{array}$

8 Analysis of Asset Utilisation, Profitability and Performance 58

$\begin{array}{llr}8.1 & \text { Learning objectives } & 58\end{array}$

$\begin{array}{llr}8.2 & \text { Business performance objectives } & 58\end{array}$

$\begin{array}{llr}8.3 & \text { Resource utilisation } & 58\end{array}$

$\begin{array}{llr}8.4 & \text { Profitability } & 64\end{array}$

$\begin{array}{ll}\text { 8.5 Assessing and building performance } & 66\end{array}$

$\begin{array}{llr}8.6 & \text { Summary } & 67\end{array}$

9 Returns to Investors $\quad 68$

$\begin{array}{llr}9.1 & \text { Learning objectives } & 68\end{array}$

$\begin{array}{llr}9.2 & \text { Investment ratios } & 68\end{array}$

$\begin{array}{lr}9.3 \text { Capital structure } & 71\end{array}$

$\begin{array}{llr}9.4 & \text { Summary } & 75\end{array}$ 
10 Analysis of Profit Pathways $\quad 76$

\begin{tabular}{ll}
10.1 & Learning objectives \\
\hline & Constructing
\end{tabular}

$\begin{array}{lll}10.2 & \text { Constructing the profit tree } & 76\end{array}$

$\begin{array}{ll}10.3 \text { Constructing a spreadsheet template for the profit tree } & 81\end{array}$

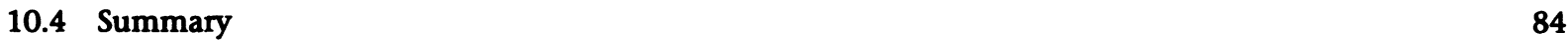

Case Study 2 Carla Firenze Trading Ltd: A Benetton Franchise 85

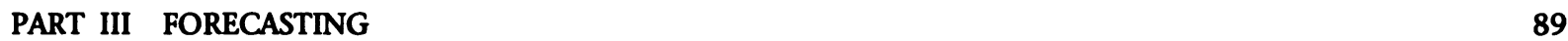

11 Time Series Analysis $r$

\begin{tabular}{ll}
11.1 & Learning objectives \\
\hline 11.2 & 91
\end{tabular}

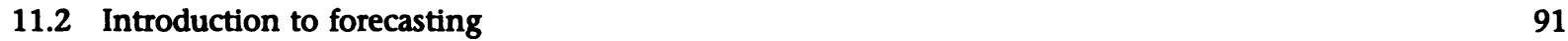

11.3 Components of a time series $\quad 92$

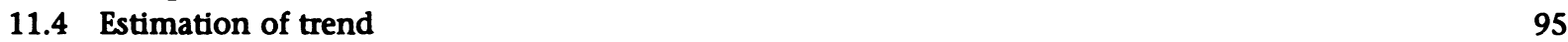

\begin{tabular}{ll}
11.5 & Forecasting the trend \\
\hline
\end{tabular}

$\begin{array}{ll}11.6 & \text { Estimating the seasonal variations }\end{array}$

$\begin{array}{lr}11.7 \text { Sales forecast } & 98\end{array}$

$\begin{array}{llr}11.8 & \text { Modifications for other time intervals } & 98\end{array}$

$\begin{array}{ll}11.9 \text { Summary } & 100\end{array}$

12 Using a Spreadsheet in Time Series Analysis $\quad 101$

$\begin{array}{ll}12.1 & \text { Learning objectives } \\ 12.2 & 101\end{array}$

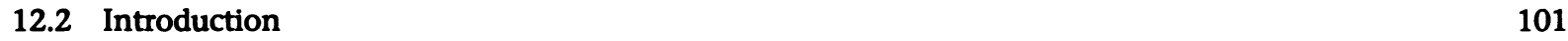

$\begin{array}{lr}12.3 \text { Historigram } & 101\end{array}$

$\begin{array}{lr}12.4 & \text { Calculation of the trend } \\ 12.5 & 102\end{array}$

\begin{tabular}{lr}
12.5 & Graphing the trend \\
\hline
\end{tabular}

$\begin{array}{lr}12.6 & \text { Calculating the seasonal variations } \\ 12.7 & 102\end{array}$

$\begin{array}{llr}12.7 & \text { Summary } & 104\end{array}$

13 Short-term Forecasting $r$

$\begin{array}{llr}13.1 & \text { Learning objectives } & 105\end{array}$

$\begin{array}{lr}13.2 & \text { Nature of short-term forecasting } \\ 13.3 & 105\end{array}$

$\begin{array}{ll}13.3 & \text { Exponential smoothing } \\ 13.4 & 106\end{array}$

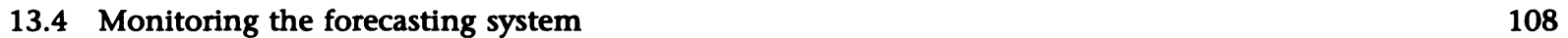

$\begin{array}{ll}13.5 \text { Summary } & 111\end{array}$

14 Forecasting Using Relationships Between Variables $\quad 112$

$\begin{array}{llr}14.1 & \text { Learning objectives } & 112\end{array}$

$\begin{array}{lr}14.2 \text { Introduction } & 112\end{array}$

$\begin{array}{llr}14.3 & \text { Scatter diagram } & 113\end{array}$

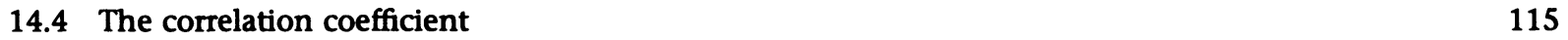

\begin{tabular}{ll}
14.5 & Interpretation of the correlation coefficient \\
\hline
\end{tabular}

\begin{tabular}{ll}
14.6 & Summary \\
\hline
\end{tabular}

15 Regression $\quad 118$

$\begin{array}{llr}15.1 & \text { Learning objectives } & 118\end{array}$

$\begin{array}{ll}15.2 & \text { Introduction } \\ 1 & 118\end{array}$

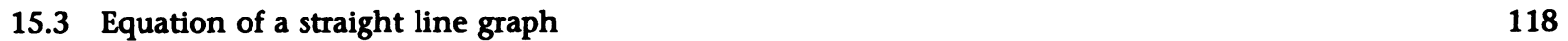

$\begin{array}{lr}15.4 & \text { Least squares regression line } \\ 15.5 & 120\end{array}$

$\begin{array}{llr}15.5 & \text { Forecasting using the regression line } & 121\end{array}$

$\begin{array}{ll}15.6 \text { Summary } & 123\end{array}$ 
16 Linear Regression on the Spreadsheet 124

$\begin{array}{llr}16.1 & \text { Learning objectives } & 124\end{array}$

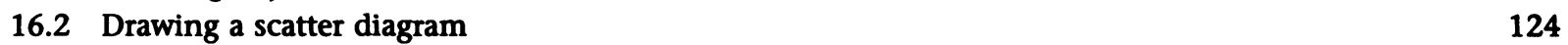

$\begin{array}{llr}16.3 & \text { Linear regression commands } & 124\end{array}$

$\begin{array}{llr}16.4 & \text { Interpretation of linear regression output } & 126\end{array}$

$\begin{array}{ll}\text { 16.5 Making predictions using the regression equation } & 128\end{array}$

$\begin{array}{ll}16.6 \text { Summary } & 129\end{array}$

17 Multiple Regression $r$

$\begin{array}{ll}17.1 & \text { Learning objectives } \\ 17.2 & 130\end{array}$

$\begin{array}{ll}17.2 & \text { Introduction } \\ 1 & 130\end{array}$

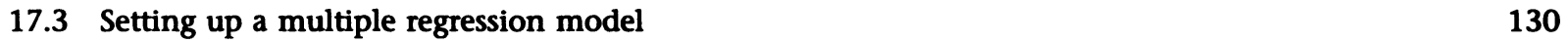

$\begin{array}{llr}17.4 \text { Warning } & 134\end{array}$

$\begin{array}{llr}17.5 & \text { Summary } & 134\end{array}$

Case Study 3 Collett Brothers plc: Forecasting to Improve Efficiency 135

$\begin{array}{lr}\text { PART IV COSTING AND BUDGETING } & 139\end{array}$

18 Introduction to Costing Systems $\quad 141$

$\begin{array}{llr}18.1 & \text { Learning objectives } & 141\end{array}$

$\begin{array}{ll}18.2 & \text { Introduction } \\ 18.3 & 141\end{array}$

$\begin{array}{lr}\text { 18.3 The need for a costing system } & 142\end{array}$

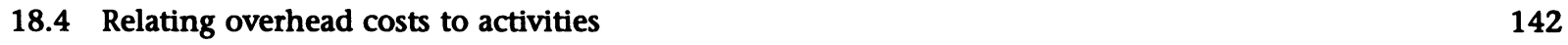

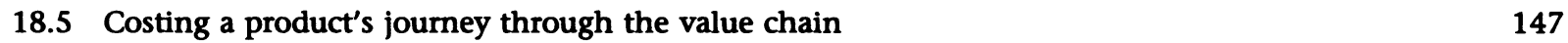

$\begin{array}{ll}18.6 \text { Summary } & 150\end{array}$

19 Budgeting $r$

$\begin{array}{llr}19.1 & \text { Learning objectives } & 151\end{array}$

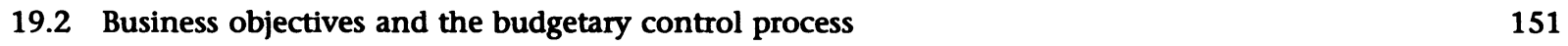

$\begin{array}{lr}19.3 & \text { Implications of budgeting for line management } \\ 19.4\end{array}$

$\begin{array}{lr}19.4 \text { Master budgets } & 153\end{array}$

$\begin{array}{lr}19.5 \text { Summary } & 157\end{array}$

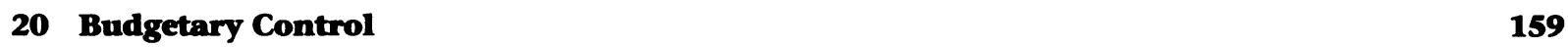

$\begin{array}{lr}20.1 & 159\end{array}$

\begin{tabular}{ll}
20.2 & Variance analysis and budgetary control \\
\hline
\end{tabular}

\begin{tabular}{ll}
20.3 & Drawing up a flexible budget on a spreadsheet \\
\hline
\end{tabular}

$\begin{array}{ll}20.4 \text { Summary } & 166\end{array}$

Case Study 4 The 'Sycamore' Public House: Introducing a Budgetary Control System 167

$\begin{array}{ll}\text { PART V DECISION-MAKING } & 171\end{array}$

21 Introduction to Decision-making $\quad 173$

$\begin{array}{llr}21.1 & \text { Learning objectives } & 173\end{array}$

$\begin{array}{ll}21.2 & \text { Introduction } \\ & 173\end{array}$

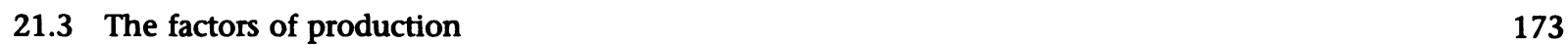

\begin{tabular}{ll}
21.4 & Classification of costs \\
\hline
\end{tabular}

$\begin{array}{ll}21.5 & \text { Determining the optimal resource mix } \\ & 175\end{array}$

$\begin{array}{ll}21.6 & \text { Summary } \\ \end{array}$ 
22 Introduction to Break-even Analysis

22.1 Learning objectives

22.2 Introduction

22.3 Calculating the break-even point

22.4 Break-even chart

22.5 Using break-even analysis to compare alternative strategies

22.6 Limitations of break-even analysis

22.7 Summary

23 Sensitivity Analysis for Break-even Analysis

23.1 Learning objectives

23.2 Sensitivity analysis

23.3 Setting up a template

23.4 Using the template

24 Short-term Decision-making

24.1 Learning objectives

24.2 Long-term and short-term decisions

24.3 Short-term decision-making: incremental analysis

24.4 Summary

25 Pricing Decisions

25.1 Learning objectives

25.2 Introduction

25.3 Strategic aspects of pricing decisions

25.4 The impact of costs on pricing decisions

25.5 Implications for pricing strategy

26 Making Long-term Investment Decisions

26.1 Learning objectives

26.2 Compound interest

26.3 Present value

26.4 Use of present value tables

26.5 Discounted cash flow calculations

26.6 Comparison of investment proposals

26.7 Internal rate of return

26.8 Summary

27 Decision-making Under Risk

27.1 Learning objectives

27.2 Games of chance

27.3 Expected monetary value

27.4 Maximising expected monetary value

27.5 Payoff matrix

27.6 Expected value of perfect information 
28 Long-term Decision-making on the Spreadsheet and Sensitivity Analysis

28.1 Learning objectives

28.2 Financial functions on the spreadsheet

28.3 Sensitivity analysis

28.4 Summary

Case Study 5 The Bloomsbury Supermarkets plc Coffee Shop Experience: 


\section{List of Figures}

2.1 Toy company: balance sheet as at 31 December 199X

2.2 Nico's business: balance sheet as at 1 January 199X

2.3 Nico's business: balance sheet as at 2 January 199X

2.4 Nico's business: balance sheet as at 3 January 199X

2.5 Nico's business: balance sheet as at 4 January 199X

2.6 Manufacturing business: balance sheet as at 6 June 199X

2.7 Manufacturing business: balance sheet as at 7 June $199 \mathrm{X}$

2.8 Manufacturing business: balance sheet as at 8 June $199 \mathrm{X}$

2.9 Manufacturing business: balance sheet as at 9 June $199 \mathrm{X}$

3.1 Jean Bean's business: balance sheet as at 1 March 199X

3.2 Jean Bean's business: balance sheet as at 31 March 199X

3.3 Jean Bean's business: cash flow statement 1 March to 31 March 199X

3.4 Jonathan's Sweets: cash flow statement 1 May to 31 May 199X

3.5 Jean Bean's business: profit and loss account 1 March to 31 March 199X
3.6 Jonathan's Sweets: profit and loss account 1 May to 31 May 199X

4.1 Sports shop: stock calculations 22

4.2 Sports shop: gross profit calculations 22

4.3 Beanstalk Ltd: trading account 1 January to 30 June $199 \mathrm{X}$

4.4 Tania's business: cash flow statement for the year 1 January to 31 December 199X

4.5 Tania's business: profit and loss account for the year 1 January to 31 December 199X

4.6 Tania's business: balance sheet as at 31 December 199X

5.1 Watch wholesaler: balance sheet as at 1 January 199X

5.2 Watch wholesaler: depreciation

5.3 Watch wholesaler: calculating the cost

5.4 Watch wholesaler: profit and loss

5.

account for the period

5.5 Watch wholesaler: cash flow statement for the period

5.6 Watch wholesaler: calculating the debtors' balance

5.7 Watch wholesaler: calculating the creditors' balance 
5.8 Watch wholesaler: balance sheet as at 31 December 199X

5.9 Joey's business: cash flow statement for the period 1 January to 31 December 199X

5.10 Joey's business: profit and loss account for the period 1 January to

31 December 199X

5.11 Joey's business: balance sheet as at 31 December 199X

6.1 Worksheet layout

6.2 Payroll data

6.3 Calculation of gross pay

6.4 Calculation of totals

6.5 Calculation of percentages

6.6 Formulae for calculation of percentages

6.7 Bar chart: MFI Group (1994), average number employed

6.8 Worksheet layout for chart drawing

6.9 Bar chart of time series data: MFI Group (1988-94)

6.10 Pie chart: MFI Group (1994), average number employed

6.11 Line chart: MFI Group (1988-94)

6.12 XY Chart (scatter diagram): relationship between number of employees and trading profit

8.1 Manufacturing company: asset turnover calculations

8.2 Liquidity

8.3 Balance sheet extracts

8.4 Comparison of liquidity

8.5 Comparison of immediate liquidity

8.6 Changes in the financial position

8.7 Calculation of ratios for Year 1

8.8 Comparison of the profitability of two businesses

8.9 Comparison of profitability ratios

8.10 Summary profit and loss accounts

8.11 Comparison of key ratios for a retailer and a manufacturer

9.1 Wimpey: calculation of investment ratios

9.2 Calculation of gearing

9.3 Comparison of two companies: financial structure

9.4 EPS calculations

9.5 ROSF calculations
9.6 Impact of gearing on performance

Comparison of company performance 73

The profit tree model

10.2 J Sainsbury plc (Group): profit and loss

account for the period March 1992 to March 1993

10.3 J Sainsbury plc (Group): balance sheet as at 12 March 1993

10.4 J Sainsbury plc (Group): profit and loss account for the period March 1993 to March 1994

10.5 J Sainsbury plc (Group): balance sheet as at 12 March 1994

10.6 The profit tree model: J Sainsbury plc (1993 and 1994 results)

10.7 Allied Domecq plc: profit and loss account for the period March 1993 to March 1994

10.8 Allied Domecq plc: balance sheet as at 5 March 1994

10.9 The profit tree model: comparison of the results of J Sainsbury plc and Allied Domecq (1994)

C2.1 Carla Firenze Trading Ltd: profit and loss account

C2.2 Carla Firenze Trading Ltd: balance sheet

11.1 Supertoys Ltd: historigram

11.2 Supertoys Ltd: working for four-quarterly moving averages

11.3 Supertoys Ltd: sales and trend

11.4 Supertoys Ltd: forecasting the trend

12.1 Spreadsheet layout

101

12.2 Spreadsheet layout with formulae

103

13.1 Softlight Vertical Blinds: sales and exponentially smoothed series

14.1 Fashion retailer: scatter diagram

14.2 Examples of scatter diagrams

114

15.1 Straight line graphs

120

66

15.2 Fashion retailer: scatter diagram and regression line

16.1 Data layout for regression calculation

16.2 Regression output from Excel

16.3 Calculation of fit using regression equation

16.4 Exercise 16.3: Regression output

Calculation of predictions from regression equation
17.1
Pandora Fashions: regression output 
18.1 Organisational structure and cost centres

18.2 Purely Travel Ltd: cost allocation and apportionment

18.3 'The Hound and Horse': profit and loss account for week ending 23 April 199X

18.4 The Hound and Horse': profit and loss account for week ending 23 April 199X, showing profit and cost centres

18.5 Lorraine's Bread Shop and Coffee Shop: profit and loss account 9 October to 15 October 199X

18.6 DPP decision tree

18.7 Costing systems and the value chain

19.1 Jeremy Weed's business: cash budget January to June 199X

19.2 Jeremy Weed's business: stock budget summary January to June $199 \mathrm{X}$

19.3 Jeremy Weed's business: debtors' budget summary January to June 199X

19.4 Jeremy Weed's business: creditors' budget summary January to June 199X

19.5 Jeremy Weed's business: budgeted profit and loss account summary January to June 199X

19.6 Jeremy Weed's business: budgeted balance sheet for end of June 199X

20.1 Toy manufacturer: profit and loss statement for the period 1 January 19X4 to 31 December 19X4

20.2 Toy manufacturer: budgeted profit and loss statement for the period 1 January $19 X 5$ to 31 December 19X5

20.3 Jinx Ltd: variance analysis

20.4 Variance analysis and management response

20.5 The budgetary control cycle

20.6 Toy manufacturer: variance analysis for the period 1 January $19 \times 5$ to 31 December 19X5

20.7 Toy manufacturer: flexed budgeted profit and loss statement for the period 1 January 19X5 to 31 December 19X5

20.8 Toy manufacturer: variance analysis for the period 1 January $19 \times 5$ to

31 December 19X5

20.9 DIY retailer: branch budget
C4.1 'The Sycamore': actual sales and costs 1988 to 1992

C4.2 'The Sycamore': budget 1992

22.1 Maria's Studio: drawing the sales revenue line on a break-even chart

22.2 Maria's Studio: break-even chart

23.1 Template for sensitivity analysis

23.2 Maria's Studio: break-even analysis

187

23.3 Kevin's Gym: break-even analysis

187

188

188

23.5 Kevin's Gym: sensitivity analysis

23.6 Exercise 23.3: sensitivity analysis

24.1 'Spread Eagle': costs and revenues

190

195

25.1 Three hairdressers: price and value positioning

199

26.1 Joan and Simon: calculating future values

204

27.1 Expected profit comparison

27.2 Susan's Biscuit Stall: gross profit calculations

28.1 Calculation of NPV: input of cash flows

28.2 Calculation of NPV: view formula mode

219

28.3 Calculation of NPV

28.4 Calculation of IRR: view formula mode

28.5 Calculation of IRR

28.6 Anna's business: discounted cash flow

28.7 Anna's business: scenario 1

28.8 Anna's business: scenario 2

223

224

225

28.10 Anna's business: scenario 4

A2.1 Allied Domecq plc: balance sheet as at

A3.1 Johnathan's Sweets: cash flow statement 1 May to 31 May 199X

A3.2 Johnathan's Sweets: profit and loss

A3.3 Janine Swift's Driving School: cash flow statement 1 September to 3 September 199X

A3.4 Janine Swift's Driving School: profit and loss account 1 September to 3 September 199X

A4.1 'White Lion': cost of goods sold 1 July to 31 July, workings

A4.2 'White Lion': gross profit 1 July to 31 July, workings 
A4.3 Vineleaves Ltd: trading account 1 July to 31 October 199X

A4.4 CardsRUs: cost of goods sold, workings

A4.5 Tania's business: cost of goods sold calculations

A4.6 Tania's business: cash flow statement for the year 1 January to 31 December 199X

A4.7 Tania's business: profit and loss account for the year 1 January to 31 December 199X

A4.8 Tania's business: balance sheet as at 31 December 199X

A5.1 Joey's business: depreciation calculations

A5.2 Joey's business: cash flow statement for the period 1 January to 31 December 199X

A5.3 Joey's business: profit and loss account for the period 1 January to 31 December 199X

A5.4 Joey's business: balance sheet as at 31 December 199X

A6.1 Final worksheet for Exercise 6.1 (numerical version)

A6.2 Final worksheet for Exercise 6.1 (view formula version)

A6.3 Template for financial statements calculations

A8.1 Changes in working capital over time

A8.2 Comparison of profitability

A8.3 Inter-firm comparison

A9.1 Impact of gearing on performance

A10.1 The profit tree model: comparison of the results of J Sainsbury plc and Allied Domecq plc (1994)

A10.2 Template for profit tree

235

236

236

237

237

237

237

238

238

239

239

240

242

243

243

244

247
A11.1 UK consumers' expenditure on clothing

250

A11.2 Scrumtello's DIY Superstore: historigram of sales

A14.1 Exercise 14.3: scatter diagram

A15.1 (a) $y=10+3 x$; (b) $y=250-10 x$;

(c) $y=0.256-x$; (d) $y=4 x$

A15.2 Scatter diagram with regression line 258

A16.1 Exercise 16.4: regression print-out 259

A17.1 Relationship between sales and floorspace

A17.2 Lively Oldies Travel Company: regression output

A18.1 Purely Travel Ltd: cost apportionment

A18.2 Lorraine's Bread Shop and Coffee Shop: profit and loss account 9 October to 15 October 199X

A19.1 John Bloggs: cash budget October to December

A19.2 John Bloggs: budgeted profit and loss account for the period October to December

A19.3 John Bloggs: budgeted balance sheet for end of December

A20.1 Toy manufacturer: budgeted profit and loss statement for the period 1 January 19X5 to 31 December 19X5

A20.2 Jinx Ltd: variance analysis

A20.3 Market trader: variance analysis for flexed budgeted profit and loss statement

A20.4 DIY retailer: template for branch budgeted profit and loss account

A22.1 Bracken Ltd: break-even chart

A22.2 Maria's Studio: new break-even chart

A23.1 Kumfee Bed Company: sensitivity analysis

A25.1 Delaney's: cash budget and variance analysis 


\section{List of Tables}

4.1 Beanstalk Ltd: stock records

4.2 Beanstalk Ltd: FIFO stock calculations

4.3 Beanstalk Ltd: WAC stock calculations

4.4 Beanstalk Ltd: LIFO stock calculations

4.5 Vineleaves Ltd: stock records

4.6 Sewing machine: straight line depreciation schedule

4.7 Sewing machine: reducing balance depreciation schedule

4.8 Brewery: comparison of the two depreciation methods

4.9 Tania's business: stock transactions

5.1 Watch wholesaler: stock transactions

5.2 Watch wholesaler: stock calculation for the period - WAC

6.1 Data for Exercise 6.3

C1.1 McTucky's Ltd: purchase of goods for resale

C1.2 McTucky's Ltd: sale of goods

C1.3 McTucky's Ltd: fixed assets

7.1 DALI: European sales data

8.1 Comparison of three companies: data on liquidity

8.2 Interpreting changes in ratios

9.1 Building and construction portfolio 16 May 1995

9.2 Portfolio performance

9.3 Food retailing statistics
9.4 Scenarios for contingency planning

9.5 Profit forecasts

10.1 Comparison of performance ratios

10.2 Impact of different scenarios on key ratios

11.1 Supertoys Ltd: sales $19 \mathrm{X0}$ to $19 \mathrm{X3}$

11.2 Supertoys Ltd: time series analysis

11.3 Supertoys Ltd: trend forecast

11.4 Calculation of average quarterly variation

11.5 Calculation of seasonal variations

11.6 Making sales forecasts

11.7 Consumers' expenditure on clothing other than footwear 1988 to 1991

11.8 Scrumtello's DIY Superstore: sales

11.9 Scrumtello's DIY Superstore: calculation of average daily variation $\quad 100$

73

13.1 Softlight Vertical Blinds: sales

13.2 Softlight Vertical Blinds: exponentially smoothed forecasts $(\alpha=0.4)$

13.3 Softlight vertical blinds: exponentially smoothed forecasts $(\alpha=0.8)$

13.4 Cycle shop: demand during 19X3 108

13.5 Cases of shampoo: weekly demand 109

13.6 Softlight Vertical Blinds: forecast errors $(\alpha=0.4)$

13.7 Softlight Vertical Blinds: smoothed mean absolute deviation $(\alpha=0.4)$ 
13.8 Washing-up liquid: monthly demand 19X3

14.1 Fashion retailer: average weekly turnover in branches

14.2 Fashion retailer: calculations of sums for evaluation of $\mathbf{r}$

14.3 Demand for sweaters and temperature

17.1 Pandora Fashions: sales

17.2 Lively Oldies Travel Company: survey results

C3.1 Leeds store: takings during trial of loyalty card

C3.2 Stockport store: daily sales

C3.3 Edinburgh store: quarterly costs of carryout bags

C3.4 Edinburgh store: customer usage of carryout bags

C3.5 Edinburgh store: predicted quarterly takings and number of items scanned

18.1 'The Hound and Horse': additional data

18.2 Lorraine's Bread Shop and Coffee Shop: additional information

C4.1 Definition of 'quality food suburban'

22.1 Maria's Studio: fixed costs

23.1 Kumfee Bed Company: choice of product projections

25.1 Own brand product lines: price comparison

25.2 Comparison of pricing techniques

25.3 Delaney's: sales forecast

25.4 Delaney's: actual results

26.1 Bravo Disposals: payment schedule

26.2 Present value of $£ 1$

26.3 Molly's investment: DCF calculation

26.4 Investment A: NPV calculation

26.5 Investment B: NPV calculation

26.6 Example in Section 26.7: NPV calculations

27.1 Susan's Biscuit Stall: distribution of daily demand

27.2 Susan's Biscuit Stall: payoff matrix

27.3 Fine Furniture Company: payoff matrix

28.1 Anna's business: initial purchases

28.2 Premier Pub Company: fixed costs of site

C5.1 Bloomsbury Supermarkets plc: proposed sales build-up curve

C5.2 Bloomsbury Supermarkets plc: cost projections
C5.3 Bloomsbury Supermarkets plc: projection of initial capital costs at $1996 / 97$ prices

C5.4 Bloomsbury Supermarkets plc: on-going capital expenditure at 1996/97 prices

C5.5 Bloomsbury Supermarkets plc: scenarios for coffee shops

A2.1 Business assets

A2.2 Koolkurls Hairdressing Salon: fixed and current assets

A4.1 Vineleaves Ltd: FIFO

A4.2 Vineleaves Ltd: WAC

A4.3 Vineleaves Ltd: LIFO

A4.4 CardsRUs: FIFO stock calculations

A4.5 CardsRUs: WAC stock calculations

A4.6 Brewery: comparison of depreciation

A4.7 Tania's business: FIFO closing stock

A5.1 Joey's business: closing stock calculations

A8.1 Comparison of company liquidity

A8.2 Advantages and disadvantages of liquidity

A8.3 Comparison of ratios over time

A8.4 Interpretation of the ratios

A9.1 Portfolio performance

A9.2 Comparison of investment ratios

A9.3 Comparison of companies $\mathbf{X}$ and $\mathbf{Y}$

A9.4 Loan finance versus share finance

A10.1 Impact of different scenarios on key ratios

A11.1 Planning horizons

A11.2 UK consumers' expenditure on clothing: time series analysis

A11.3 Scrumtello's DIY Superstore: predictions of trend for Week 5

A11.4 Scrumtello's DIY Superstore: forecast sales for Week 5

A12.1 Spreadsheet layout with formulae for Exercise 12.1

A13.1 Cycle shop: demand during 19X3

A13.2 Softlight Vertical Blinds: forecast

A13.3 Washing-up liquid: monthly demand 19X3, data set (a)

A13.4 Washing-up liquid: monthly demand 
A13.5 Washing-up liquid: monthly demand 19X3, data set (c)

A15.1 Slope and intercept: results

A25.1 Own brand product lines: comparison of strategic objectives

A25.2 Evaluation of cost-plus pricing

A25.3 Delaney's: break-even analysis based on projection

A25.4 Delaney's: actual gross margins

A25.5 Delaney's: break-even analysis based on actual results

A25.6 Delaney's: project costs affecting short-term decisions
A26.1 Bright Office Company: schedule of payments

274

255

A26.2 Bright Office Company: schedule of payments using present value tables 275

272

272

A26.3 Danny: DCF calculation

275

A26.4 Ahmad: DCF calculation

275

A26.5 Exercise 26.6: NPV calculations

273

273

(rate $=10 \%$ )

276

A26.6 Exercise 26.6: NPV calculations (rate $=9 \%)$

276

273

A27.1 'Brown Bear' pub: payoff matrix

277

A28.1 Premier Pub Company: expected cash flows 


\section{Acknowledgements}

The authors and publishers acknowledge with thanks permission from the following to reproduce data:

Claudio Vignali and Barry J. Davies of the Manchester Metropolitan University for the data in Case Study 2.

Neville Atkinson of Allied Domecq plc for the data in Case Study 4.

\section{Economic Trends.}

The following information sources were used in compiling the raw data which were reworked into simplified examples and exercises in the text:

Allied-Lyons plc, Annual Report and Accounts, 1993-1995.

MFI plc, Annual Report and Accounts, 1988-1995.

J Sainsbury plc, Annual Report and Accounts, 1989-1995.

Kwik Save plc, Annual Report and Accounts, 1993-1995.

The share performance data on Wimpey, Barratt, Banner and Beazer Homes and Sainsbury and Kwik Save were extracted from publicly available information sources on 16 May 1995.

The price comparison in Table 25.1 serves to illustrate a point of principle only. It is loosely based on an ad hoc collection of prices during a shopping trip and the prices presented may bear no resemblance to real prices currently charged. 